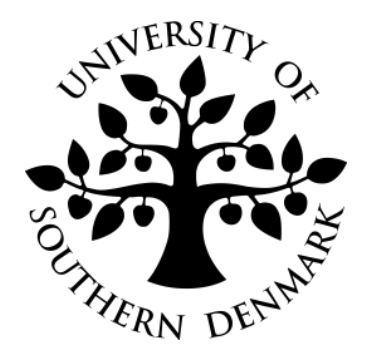

\title{
Innovations in mortgage finance and the onset of the Great Recession in a small open economy with a euro peg
} by

Thomas Barnebeck Andersen and Nikolaj Malchow-Møller

Discussion Papers on Business and Economics

No. $5 / 2015$

FURTHER INFORMATION Department of Business and Economics Faculty of Business and Social Sciences University of Southern Denmark Campusvej 55, DK-5230 Odense M Denmark 


\title{
Innovations in mortgage finance and the onset of the Great Recession in a small open economy with a euro peg
}

\author{
Thomas Barnebeck Andersen and Nikolaj Malchow-Møller \\ Department of Business and Economics, University of Southern Denmark
}

\section{March 2015}

\begin{abstract}
The Global Financial Crisis (GFC) of 2008 hit Denmark particularly hard. In this paper we argue that a combination of innovation in mortgage finance and the need to defend a euro exchange rate peg was partly responsible. Sustained pressure against the Danish krone forced the central bank to increase policy interest rates consecutively in the last quarter of 2008. Monetary tightening in the midst of the GFC deepened the ongoing recession for the usual Keynesian aggregate demand reasons. Innovations in mortgage finance, which had made the economy more sensitive to changes in the policy rate, exacerbated this effect.
\end{abstract}

JEL Classification: E2, E3, E4, F33, G210

Keywords: Global Financial Crisis, Great Recession, currency peg, financial innovation, adjustable-rate mortgages

Acknowledgements: We thank Mikkel Barslund, Thomas Harr, Jesper Gregers Linaa, Morten Skak, and Peter Sandholt Jensen for helpful discussion about this project. We also thank an anonymous referee for comments that helped us significantly improve the paper. Errors and omissions belong only to the authors.

Contact details: Andersen (barnebeck@sam.sdu.dk) and Malchow-Møller (nmm@sam.sdu.dk). 


\section{INTRODUCTION}

The Global Financial Crisis (GFC) of 2008 hit Denmark particularly hard. In this paper we argue that a combination of innovation in mortgage finance, specifically the introduction of adjustable rate mortgages (ARMs), and the need to defend the euro peg was partly responsible.

Denmark introduced ARMs in 1996; a loan type which soon became very popular (Realkreditrådet, 2012). The main advantage of ARMs is that the interest rate will usually be lower than the interest rate on a fixed-rate loan; the main disadvantage is that borrowers do not know future interest rates with certainty, as these will change throughout the duration of the loan. Specifically, interest rates on ARMs are commonly determined at end-of-year auctions with a frequency of 1,3 , or 5 years. The upshot of this is that the Danish economy has become increasingly sensitive to changes in the short end of the yield curve (Danmarks Nationalbank, 2009; Johansen and Trier, 2013).

The proliferation of ARMs is problematic because Denmark operates a conventional currency peg. ${ }^{1}$ The peg entails that monetary policy is directed exclusively at keeping the krone stable vis-à-vis the euro, whereas other considerations, such as business-cycle developments, are not taken into account (Danmarks Nationalbank, 2009). In times of depreciation pressure on the krone, the central bank may increase short-term interest rates nontrivially, as it sees fit, and this may spill over into interest rates on ARMs.

When the GFC hit in earnest in the autumn of 2008, increased uncertainty prompted foreign exchange to flow out of smaller capital areas and into larger ones; and despite its credibility, the Danish peg came under sustained pressure. This led the Danish central bank to increase monetary policy rates at a time when other central banks were lowering policy rates in order to support their respective domestic financial sectors. In late October 2008, the policy-interestrate spread between Denmark and the Eurozone reached a staggering 175 basis points (up from 25 basis points in 2007Q1). This was enough to once again make market participants turn towards Danish kroner. The policy-interest-rate spread was normalized by 2009Q3, whereas

\footnotetext{
${ }^{1}$ Denmark has operated a currency peg since 1982-first against the D-mark and from 1999 against the euro. The country has formally participated in ERM II since 1 January 1999, and the Danish krone observes a central rate of 7.46038 kroner to the euro with a narrow fluctuation band of $\pm 2.25 \%$.
} 
the spread between Danish and German short-term $(3 \mathrm{~m})$ money-market interest rates was normalized by 2010 Q3.

There can be no doubt that raising interest rates in the midst of the most virulent global financial crisis in more than 75 years impaired the overall health of the economy. ${ }^{2}$ Yet beyond traditional Keynesian effects of monetary tightening on aggregate demand, tightening also hurt aggregate demand via its impact on homeowners with ARMs. Specifically, in December 2008 some 200,000 Danish households (7.7\% of all households) needed to refinance their ARMs, and monetary tightening worsened the economic outlook for these families. In this sense, the Danish economy had to defend the euro peg at the worst time imaginable, i.e., not just during a massive global downturn but also just prior to a major ARM auction.

Consequently, the main argument of the present paper is that the combination of innovation in mortgage finance and the need to defend the euro peg was an important contributing factor to the unexpected depth and duration of the recession as well as the prolonged recovery in Denmark. At the time of writing, Denmark's economy still has not made up for lost ground since 2008. Indeed, according to OECD data (Economic Outlook No. 95, May 2014, OLIS version), the Danish economy (as measured by real GDP) grew at an average annual rate of $-0.67 \%$ between 2008 and 2013. Furthermore, according to the OECD’s May 2014 economic projection, Denmark will not have managed to surpass its 2008 real GDP level by 2015.

Danish central bankers have arguably learned the hard way that the cost of raising the monetary policy rate in order to defend the euro peg has increased significantly as a result of financial innovation. This will make it harder to defend the peg in the future, which raises the question of whether the proliferation of ARMs is at all consistent with a fixed-exchange-rate policy in the long run. We approach this difficult question in the penultimate section of the

\footnotetext{
2 The move to raise interest rates is reminiscent of the 1930s when countries raised interest rates in order to avoid the hemorrhaging of gold reserves. The US famously raised interest rates in 1931 when there was a threat to the country's gold commitment. This move is generally thought to have driven the US economy deeper into depression (Eichengreen and Temin, 2000). The issue of raising interest rates in the midst of a crisis also caused a lot of controversy in connection with the Asian crisis of 1997/98. Stiglitz (2002) has thus strongly criticized the IMF-mandated increases in interest rates, which, according to him, generated a string of bankruptcies that deepened the confidence crisis and further contributed to the slowdown.
} 
paper, where we also discuss some of the new and challenging trade-offs that Danish policymakers face with respect to maintaining the euro peg in the post-GFC environment.

On a general level, we believe that there are a number of reasons as to why monetary policy should receive careful attention in any serious discussion of the weak Danish growth performance since 2008. A leading explanation for the weak performance appears to be a combination of a housing bubble and economic overheating (Sørensen, 2010, 2012; Kraka, 2014). While these are surely important contribution factors, they are unlikely to be the full story. First, in 2008 there were 12 OECD countries with a higher output gap (i.e., more overheated) than Denmark (in 2007 the corresponding number was 10), which suggest that comparatively speaking overheating was not a major problem. Moreover, the three countries just behind Denmark (Mexico, Belgium, and Switzerland) and the three countries just ahead of Denmark (Norway, Austria, and Luxembourg) in terms of economic overheating (as measured by the 2008 output gap) all saw positive average annual post-GFC economic growth. Add to this that monetary easing is better than the output gap at predicting cross-country post-GFC growth in the non-Eurozone OECD countries (Andersen and Malchow-Møller, 2014). Second, while the unwinding of the housing bubble unquestionably contributed to the downturn, we will argue below that timing issues in the fall of house prices suggest that household consolidation due to excessive loan-to-value ratios does not explain the disproportionate plunge in consumption in 2008Q4. Monetary policy, on the other hand, can explain it. Add to this that Denmark implemented a large discretionary fiscal stimulus in 2009 and, at the same time, the Danish economy has the largest automatic stabilizers in the OECD area (OECD, 2009). Consequently, an inadequate fiscal stimulus is unlikely to explain the protracted Danish recovery compared to other OECD countries. The OECD (2009) also pointed out that Denmark has a strong, credible and forward-looking fiscal framework. Hence, fiscal policy is likely to be quite effective in Denmark. For these reasons, monetary policy must be a prime suspect.

The remaining discussion is structured as follows: Section 2 provides some macroeconomic background, while Section 3 discusses how interest rates affect aggregate demand in the Danish economy. Section 4 uses simple econometrics to gauge the effect of monetary policy on consumption growth, while Section 5 examines whether a distinct uncertainty effect was at work in 2008Q4. Section 6 turns to a discussion of some of the new and difficult challenges 
Danish policymakers face in light of the recent experience of managing the euro peg. Finally, Section 7 concludes.

\section{BACKGROUND}

EconomiC GROWTH: Denmark entered the GFC in relatively good shape. The country has high income per capita, an equal income distribution, high labor-market participation, a flexible workforce coupled with a strong social safety net (the so-called flexicurity model), and a strong fiscal framework (OECD, 2009). Moreover, when the GFC erupted in earnest in the autumn of 2008, Denmark had low public debt and a comfortable surplus on both the current account and the primary budget balance. Add to this that Denmark is consistently ranked among the best countries in terms of "ease of doing business" according to the World Bank's Doing Business Indicators. For these reasons, the $\operatorname{OECD}$ (2009, p. 18) noted that the crisis in Denmark "is proving less painful than in many other OECD countries." This proved to be a premature conclusion. Of the 34 OECD countries, only five countries were hit harder than Denmark during the Great Recession years of 2008 and 2009 , cf. Figure $1 .^{3}$

\section{Insert Figure 1}

Understanding how countries fared during the Great Recession is important, not least because average annual growth from 2007 to 2009 strongly predicts average annual growth from 2007 to $2013 .{ }^{4}$ It is therefore not surprising that of the 34 OECD countries only seven performed worse than Denmark during the full period. Indeed, as noted in Section 1, Danish real GDP was smaller in 2013 than in 2008. Accordingly, understanding why Denmark was hit so hard by the GFC is likely to provide important insights into its dismal post-GFC macroeconomic performance.

INTEREST RATES: As noted in Section 1, the logic of the fixed-exchange-rate regime compelled the Danish central bank to raise policy interest rates in the midst of the most severe financial

\footnotetext{
${ }^{3}$ Among these five countries, Finland, a well-run Nordic country, arguably stands out. The worldwide recession and the attendant collapse in trade hit Finland particularly hard. Real GDP fell by more than $9 \%$ from the peak in mid-2008 to 2009Q2, driven to a large extent by declining export volumes (which fell by close to one third). Finnish exports depend strongly on the Russian market, which was hit hard by the crisis (OECD, 2010).

4 The correlation between OECD-country growth rates in the two periods is 0.61 ( $p$-value is 0.0001 ).
} 
crisis in more than 75 years and accept a widening spread vis-à-vis the ECB. ${ }^{5}$ This happened at a time when other central banks were lowering their interest rates aggressively in support of their domestic financial sectors.

More specifically, the Danish krone weakened after the collapse of Lehman Brothers in September 2008. This was due to a desire on part of foreign banks and investors to withdraw from minor currencies as the financial crisis intensified (IMF, 2010). While rebalancing of portfolios probably accounted for the bulk of the pressure, there were also indications of speculative activity against the krone (Økonomi- og Erhvervsministeriet, 2013). To stabilize the krone the Danish central bank intervened heavily in the foreign-exchange market. With unabated pressure on the krone, the central bank eventually raised its monetary policy interest rates, whereby the spread to the euro area widened. As of 8 October 2008, the central bank lending rate was raised by 0.4 percentage point. At midday on the very same day, the ECB announced its decision to lower interest rates by 0.5 percentage point (citing the intensifying financial crisis as the background), for which reason the spread widened even further. Yet the krone was still under pressure, and so on 24 October the Danish central bank raised the lending rate by a further 0.5 percentage point, thus widening the policy interest-rate spread to 1.75 percentage points, cf. Figure 2.

\section{Insert Figure 2}

According to the simple expectations theory of the term structure (see e.g. Romer 2012, Ch. 11; Bénassy-Quéré et al., 2010, Ch. 4), money-market interest rates depend on the average of expected policy rates over the lifetime of the money-market instrument plus a term premium. Under normal conditions, when the term premium is approximately constant and when expectations are firmly anchored, changes in money-market interest rates should therefore follow changes in expected policy rates quite closely. Under financial turmoil the co-variation is

\footnotetext{
${ }^{5}$ This was of course a direct implication of being outside the Eurozone. Another implication of being outside the Eurozone was that it took a longer time for Denmark's central bank to arrange a liquidity agreement with the Federal Reserve than it did for the ECB. Moreover, being outside the Eurozone also complicated the communication of the content of the rescue packages for Danish banks to financial markets. Both factors added to uncertainty and thus pushed up the level of money-market interest rates (Økonomi- og Erhvervsministeriet, 2013).
} 
likely to be less intimate. Yet as shown in Figures 3 and 4, the increasing spread between Danish and ECB policy rates discussed above is indeed mirrored in 3m-money-market rates. Specifically, Figure 3 shows the level of the Danish and the German short-term (3m) interest rates (note that, as all Eurozone short-term interest rates are the same, the thin line is in fact the Eurozone short-term interest rate), while Figure 4 shows the spread. ${ }^{6}$ By 2009Q1 excess demand for euro liquidity resulted in a quarterly $3 \mathrm{~m}$-money-market spread between Denmark and Germany of 190 basis points.

\section{Insert Figures $3 \& 4$}

The Danish-German long-term (10y) interest-rate spread also increased (note that unlike short-term interest rates, Eurozone long-term interest rates are country specific, for which reason the German 10y interest rate is not equal to the Eurozone ditto), cf. Figure 5. However, the effect on the Danish long-term interest rate was much smaller. The spread thus "only" increased by up to 50 basis points, which substantiates that the short-term increases were expected to be transitory.

\section{Insert Figure 5}

\section{INTEREST RATES AND AGGREGATE DEMAND}

Higher short-term interest rates will influence aggregate demand, and thus economic growth, in several ways. First, standard Keynesian macroeconomic theory holds that a higher shortterm policy interest rate will reduce growth to the extent that it increases long-term (real) interest rates, as these are the ultimate drivers of aggregate demand (Bénassy-Quéré et al., 2010). ${ }^{7}$ Second, interest rates at the shorter end of the maturity spectrum directly influence the cost of adjustable-rate mortgages (ARMs), which were introduced in Denmark in 1996, and

\footnotetext{
6 The spectrum of interest rates is very broad, depending on quality of instruments, horizon, etc. Here we focus on short-term (money market) interest rates, as it is these that are very much influenced by monetary policy. While the central banks influence policy rates, such as repo rates, the standard measure used for short rates is usually the $3 \mathrm{~m}$ interbank offer rate (Carnot et al., 2011). We will stick to this convention here. For completeness, however, note that the correlation between central bank's main policy rate and the three-month interest rate is more than 0.98 in both Denmark and Germany during 1999Q1-2014Q1.

${ }^{7}$ As shown in Figures 4 and 5, and as argued above, long-term rates in Denmark seem to have been affected by the move in short-term rates during the crisis.
} 
hence have a direct effect on (disposable) income, which is not captured by movements in the long-term interest rate. Given the widespread popularity of ARMs in the Danish economy, this direct effect may be substantial. ${ }^{8}$ The Danish Ministry of Business and Growth reports that an increase in the short-term interest rate of 1 percentage point will increase homeowners' interest expenses by the equivalent $1.2 \%$ of their income (Økonomi- og Erhvervsministeriet, 2010), whereas the Danish central bank reports that it will increase households' interest expenses by the equivalent of $1 \%$ of private consumption after tax (Danmarks Nationalbank, 2009). Third, an increase in uncertainty over the level and duration of short-term interest rates is also likely to influence aggregate demand through a real-options effect and a precautionarysavings effect (Romer, 1990; Dixit and Pindyck, 1994; Bloom, 2014), and this will be the case even if the expected level of interest rates remains the same. The second and the third mechanism have likely become increasingly important in Denmark in recent years due to the introduction and proliferation of ARMs.

Danish ARMs are long-term mortgage loans (often 30-year loans) where the interest rate is adjusted at specific intervals, often annually. Mortgage institutions fund the long-term loans via inconvertible short-term bonds usually with redemption in December (Nielsen, 2007). ${ }^{9}$ After redemption new short-term bonds are issued but for a smaller amount, the difference between year $t$ and $t-1$ being the installments paid by the borrowers. As noted in Section 1, the main advantage of ARMs is that interest rates are generally lower than those of fixed-rate loans; the drawback is that borrowers do not know the size of next year's installments (OECD, 2006). At the end of 2008, 55\% of all Danish mortgage debt was ARMs, against 22\% at end-2002 and 6\% at end-1999. Moreover, the largest share of these loans is by far loans with an annual interest rate adjustment (Danmarks Nationalbank, 2009).10 Danish homeowners, and therefore the

\footnotetext{
8 The introduction of ARMs changed the structure of mortgage debt significantly. As late as 1999 virtually all mortgages were fixed-rate loans, but by 2006 these accounted for only about $40 \%$ of total outstanding mortgage debt (OECD 2006).

${ }^{9} \mathrm{~A} 1$-year ARM is funded via 1 year bonds; a 2-year ARM is funded via 1-year and 2-year bonds; a 3-year ARM is funded via 1, 2 and 3-year bonds; and so on and so forth (Nielsen, 2007).

10 The short-term bonds behind ARMs are very safe. In fact, during its two centuries of existence, the Danish mortgage system has ensured that investors have always been paid in full (Realkreditrådet, 2012). The key feature of the Danish mortgage system is the so-called "balance principle" when issuing bonds, which limits the risk mortgage banks (MBs) may incur. When MBs grant a customer a loan for the purchase of real property, they must first raise the funds. MBs will issue and sell bonds to investors, which then fund the loans. During the term of
} 
economy as a whole, had as a consequence become increasingly (short-term) interest-rate sensitive prior to the GFC (Johansen and Trier, 2013).

To get a sense of the scale of ARMs in the Danish economy, we next discuss banks' and households' exposure to them. With respect to banks, almost 19\% of bank assets in 2008 were in the form of bonds according to the Danish Bankers Association. Of these, almost three quarters were in the form of short-term bonds, which banks use actively in their liquidity management. The bulk of these short-term bonds are the funding counterpart of the ARMs, with banks holding about one third of all the short-term bonds behind ARMs (Gundersen et al., 2011). With respect to households, we have detailed information about their debt in 2010 , because Danish mortgage banks provided individual-level data to the Danish central bank, which it subsequently merged with income, tax, and wealth data from a population-wide register of individuals (results are reported in Andersen et al., 2012). We expect this to provide a largely true and fair picture of the situation two years earlier, i.e., in 2008. The dataset comprised 2.6 million households (i.e., basically all Danish households). About two thirds of the debt of all Danish households was mortgage debt. Just under one third was bank debt, while about one percent was debt to other creditors. 38\% of all 2.6 million Danish families had a mortgage, with mortgage debt representing $85 \%$ of these 988,000 households' total debt. 256,449 households had an ARM with amortization (68\% had only this type of mortgage while $32 \%$ had other types of mortgages as well) and 347,761 had an ARM with deferred amortization (77\% had only this type of mortgage while $23 \%$ also had other types of mortgages).

In December 2008 about 200,000 Danish homeowners needed to refinance their ARMs (i.e., 7.7\% of all Danish households). ${ }^{11}$ Higher interest rates, which were the result of the need to defend the krone, directly impacted the December 2008 auctions and thus the interest rate costs of homeowners with ARMs throughout 2009.12 In addition, uncertainty about the

\footnotetext{
the loan, borrowers make principal and interest payments to MBs, which then transfer the sums to investors. MBs are unaffected by any changes in loan rates. In case of falling interest rates, the MB will receive a lower interest payment from the borrower, but is only required to transfer the same lower interest amount to investors (bondholders). Consequently, such changes affect only investors and borrowers (Realkreditrådet, 2012).

11 An interest rate set on the December auction has force as of 1 January.

12 Prior to the GFC, the OECD warned about the possibility of something resembling such an unhappy scenario
} 
duration of elevated interest rates conceivably prompted homeowners with ARMs to further cut back on consumption in mid 2008Q4 (i.e., before the auction).

Consequently, there can be little doubt that the need to defend the euro peg at the worst possible cyclical moment (i.e., during a major global downturn and at the time of a major ARM auction) weakened the Danish economy nontrivially in 2008Q4. If we look at households' purchases of vehicles, Denmark experienced a plunge of more than 30\% during 2008Q4; in comparison, the reduction during 2008Q3 was only 8.3\%. Undoubtedly, turmoil in the global economy (unrelated to Danish monetary policy) is likely to explain a part of the drop. However, compared to the other OECD countries, the Danish plunge in consumption is also large proportionally speaking. In fact, Denmark experienced the fourth largest proportional drop (of all OECD countries) in real private final consumption expenditure during 2008Q4, cf. Figure 7. Compared to its neighbors as well as the Eurozone and OECD averages, Denmark's consumption trajectory also remained subdued throughout the ensuing quarters, cf. Figure 8.

\section{Insert Figures 6, 7 and 8}

Denmark experienced a major housing bubble during 2005-06; and high indebtedness among homeowners together with falling house prices around 2007 resulted in increasing loan-tovalue (LTV) ratios, which created a need for consolidation among homeowners (Andersen et al., 2014). How do we separate this effect from the effect of monetary policy? As noted in Section 1, timing issues hold useful information. More concretely, house prices started to decline as early as 2006Q3 for owner-occupied flats, cf. Figure 9; and while (realized) prices did fall by more than 7\% during 2008Q4, they did the same during 2009Q1 without a major fall in spending on vehicles, cf. Figure 6. With respect to one-family houses, a similar story can be told. Consequently, the effect of rising LTV ratios is unlikely to be the main driver behind the precipitous fall in consumption during 2008Q4.

\section{Insert Figure 9}

(see OECD, 2006, p.135). 


\section{REGRESSION ANALYSIS}

This section considers the consequences of having to defend the euro peg through the lens of regression analysis. Our empirical approach entails estimating a simple autoregressive prediction model and then checking whether interest rate developments predict the percentage change in household consumption. We are particularly interested in the DanishGerman short-term-interest-rate spread, as it captures the amount of pressure on the peg.

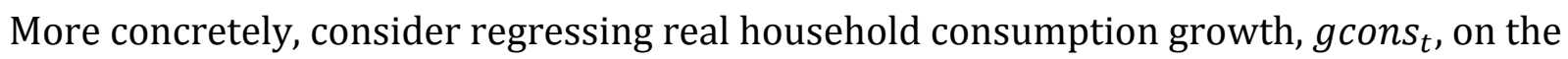
interest-rate spread between the Danish and the German 3m-money-market interest rate (i.e., $\operatorname{spread}_{t}=r_{t}^{3 m}-r_{t}^{3 m G}$ ), the Danish 10y interest rate, $r_{t}^{10 y}$, the Danish $3 \mathrm{~m}$ interest rate, $r_{t}^{3 m}$, the percentage change in house prices, ghouse $_{t}$, and one-period lagged real household consumption growth, gcons $_{t-1}$. That is, consider the following specification:

(1) gcons $_{t}=b_{0}+b_{1}$ spread $_{t}+b_{2} r_{t}^{10 y}+b_{3} r_{t}^{3 m}+b_{4}$ ghouse $_{t}+b_{5}$ gcons $_{t-1}+e_{t}$

The spread coefficient, $b_{1}$, is supposed to capture non-Keynesian effects of having to defend the euro peg. More precisely, a large (positive) spread implies a strong depreciation pressure on the krone. Strong depreciation pressure on the krone means that there is stress in the banking system, due to, among other things, difficulties in obtaining short-term funding. It also means that there is a great deal of uncertainty about the level of future short-term interest rates, which may lead households with ARMs to cut back on consumption. Consequently, we expect that $b_{1}<0$.

In theory, a higher (real) interest rate has an ambiguous effect on consumption growth. Specifically, there is a substitution effect (lower relative price of future consumption), which lowers current consumption. There is also an income effect, which is positive because the household sector is a net creditor. Finally, there is wealth effect (value of assets goes down), which likely lowers consumption. The sign of $b_{2}$ is therefore a priori undetermined.

The current short-term interest rate, $r_{t}^{3 m}$, captures the direct costs of financing ARMs. This would suggest that $b_{3}<0$. Much lending to finance household consumption is also at a 
variable rate, which further reinforces the negative effect on consumption growth of higher short-term interest rates.

Both $b_{2}$ and $b_{3}$ thus capture Keynesian effects of monetary policy. It must be stressed, of course, that the coefficients should not be given any causal interpretation, as interest rates are also be affected by real changes in the economy, including the development in household consumption.

We include house price dynamics as well, as Denmark experienced a large house price bubble in the years leading up to the crisis. We expect higher house prices to stimulate consumption growth, i.e., we expect $b_{4}>0$.

The inclusion of the lagged value of real consumption growth in equation (1) means that we are basically fitting a simple autoregressive prediction model. Moreover, the presence of a lagged endogenous variable is likely to render equation (1) dynamically complete (Wooldridge 2013). Mean reversion suggests that $b_{5}<0$.

We employ a sample with pre-crisis, crisis, and post-crisis observations. If we exclude crisis and post-crisis observations, it will be more difficult to pick up the consequences of financial innovation. This is so for two reasons. First, there is limited variation in the Danish-German $3 \mathrm{~m}$-interest-rate spread in the years prior to 2008. The standard deviation of the $3 \mathrm{~m}$-interestrate spread is 0.22 during 1999Q1-2008Q1 and 0.55 during 2008Q2-2014Q1. Second, recall from Section 3 that at the end of 2008, 55\% of all Danish mortgage debt was ARMs, against $22 \%$ at end-2002 and 6\% at end-1999. This means that even with variation in the spread, an effect of monetary policy running through ARMs was likely to be quantitatively unimportant in 1999, moderately important in 2002, and quite important in 2008.

Turning to the econometric results, column 1 of Table 1 reports results from OLS estimation of equation (1). ${ }^{13}$ Inspection of the column reveals that all coefficients are significant at ten percent or less save for the short-term Danish interest rate, which comes close with a $p$-value of 0.105 . The coefficients also behave according to a priori expectations: the spread is negative,

\footnotetext{
${ }^{13}$ Appendix Table A1 provides a graph of all the time series used in this section.
} 
the $10 \mathrm{y}$ interest rate is positive, the $3 \mathrm{~m}$ interest rate is negative, the percentage change in house prices is positive, and the autoregressive part displays regression towards the mean. This relatively parsimonious empirical specification explains more than one quarter of the variation in real household consumption growth over the period 1999Q1-2014Q1. In column 2 we change the sample period to 2002Q1-2014Q1, which changes nothing qualitatively.

In columns 3 and 4 we replace gcons $_{t}$ and gcons $_{t-1}$ in equation (1) by respectively gcar $_{t}$ and gcar $_{t-1}$, where gcar is (seasonally and trading-day adjusted) quarterly growth in household's purchases of vehicles. Both non-Keynesian and Keynesian effects are still statistically significant. Coefficients, however, are numerically much larger in columns 3 and 4 than in columns 1 and 2. Yet relative magnitudes are similar, as is evident upon comparing the standardized (beta) coefficients reported in square brackets. Consequently, purchases of vehicles tell a similar story to overall consumption.

According to the standardized coefficients in square brackets, one standard deviation increase in the spread, the Danish 10y interest rate, and the Danish $3 \mathrm{~m}$ interest rate are associated with respectively a 0.35 standard deviation decrease, a 0.46 standard deviation increase, and a 0.36 standard deviation decrease in real consumption growth. As such, changes in interest rates (and thus monetary policy actions) predict changes in consumption in an economically meaningful way. Moreover, the fact that the spread is a significant predictor (economically as well as statistically) of consumption growth in equation (1) means that pressure on the euro peg is generally associated with lower aggregate demand growth in Denmark through a nonKeynesian channel.

\section{Insert Table 1}

\section{EVIDENCE OF AN UNCERTAINTY EFFECT}

In this section we provide some simple evidence, which suggests that (an unspecified) part of the non-Keynesian effect of monetary policy in 2008Q4 may have been running through an uncertainty effect. ${ }^{14}$ The simple idea is that uncertainty over the refinancing of ARMs, driven in

\footnotetext{
14 There is a growing literature that emphasizes the importance of macroeconomic and policy uncertainty for
} 
turn by the need to defend the euro peg, caused homeowners to precipitously cut back on private final consumption expenditure, i.e., before the actual reset of ARMs. ${ }^{15}$

A theoretical motivation for the uncertainty effect runs as follows: When future income is highly uncertain, there is a trade-off between purchasing the durable and waiting. If the consumer makes the purchase, she gets the utility from the durable, but at the cost of being locked in to the durable before the level of future income is known. If she does not make the purchase, she does not receive the utility from the durable (in fact, she may be very far from the optimal level of consumption); at the same time, however, she is not locked in to the durable, for which reason she is able to choose the appropriate level of durables consumption once uncertainty about future income is resolved (Romer, 1990). In the language of real options, there is an option value of waiting to consume when uncertainty is high (see Dixit and Pindyck, 1994). A rise in uncertainty should also lead consumers to increase precautionary savings, which also reduces expenditures on consumption (Romer, 2012). ${ }^{16}$ Conceptually, this channel (which depends on the convexity of marginal utility of consumption) is quite distinct from the option-value effect (which depends on irreversibility in the consumption decision).

Being a latent variable, uncertainty can only be measured indirectly. Bloom et al. (2013) therefore suggest newspaper searches on the word "uncertainty" as an indirect gauge of uncertainty. Alexopoulos and Cohen (2009) also argue that people learn about uncertainty through the media. Baker et al. (2012) show that counts of the frequency in which leading US

\footnotetext{
economic growth and fluctuations more generally. Bernanke (1983) is an early contribution. He shows that a temporary increase in uncertainty can cause an immediate decline in firms' investment. Bloom et al. (2012) is a recent contribution. They develop a measure of uncertainty using census microdata from 1972 to 2010, which they use to show that uncertainty rises sharply in recessions. Next they build a DSGE model in order to investigate the effects of uncertainty on aggregate outcomes. Model simulations demonstrate that growing uncertainty makes it optimal for firms to adopt a wait-and-see policy, which in turn leads to significant falls in hiring, investment, and output. Bloom (2014) provides a survey of this literature in which he notes that there is a general appreciation among leading policymakers of the important role played by uncertainty in driving the Great Recession (2008-09) and the sluggish recovery.

15 The initial uncertainty impulse in the market for ARMs may have spilled over to other parts of the economy. Specifically, uncertainty about the economic outlook due to the reduction in consumption spending may have led firms to put off investment plans until the economic outlook became clearer (i.e., firms adopted a wait-and-see strategy), which in turn caused additional uncertainty. In this sense, an initial impulse may set in motion uncertainty dynamics that contain elements of a feedback loop (see Bloom, 2014).

${ }^{16}$ Fernández-Vallaverde et al. (2011) argue that this effect is likely to be high in a small open economy.
} 
newspapers contain articles using the words "uncertain" or "uncertainty" and "economy" or "economics" is strongly countercyclical. Using a newspaper-based approach to measure uncertainty therefore appears to be a fruitful strategy.

In 2008Q4 all major nationwide Danish newspapers ran articles on the uncertain situation facing homeowners with ARMs. A search in the Danish media database INFOMEDIA on the word "rentetilpasningslån" (i.e., adjustable-rate mortgage(s); note plural and singular is the same in Danish for ARMs) reveals that during 2008Q4 there were 145 articles featuring this word in the nationwide Danish newspapers: Berlingske, BT, Børsen, Ekstra Bladet, Information, Jyllands-Posten, Kristelig Dagblad, Politiken, and Weekendavisen. During 2006Q4, 2007Q4, 2009Q4, 2010Q4, and 2011Q4 there were respectively 53, 45, 89, 100, and 59 articles. If we refine the search to articles including the words "rentetilpasningslån" and "usikkerhed" (i.e., adjustable-rate mortgage and uncertainty), we find 4, 5, 30, 4, 7, and 7 occurrences for respectively 2006Q4, 2007Q4, 2008Q4, 2009Q4, 2010Q4, and 2011Q4. Figure 10 provides a visual display, which strongly suggests that 2008Q4 was an outlier with respect to media interest in ARMs and the uncertainty that surrounded this particular mortgage instrument.

\section{Insert Figure 10}

As one would expect, the specific content of the articles in 2008Q4 generally focused on the uncertain situation facing homeowners with ARMs. On 8 October 2008, Berlingske for instance ran a piece with the headline: "Borrowers with ARMs may be in for an interest rate slap". ${ }^{17}$ The article reports that many homeowners with ARMs can expect an economic "slap in the face" due to higher interest rates. BT ran a piece on the very same day with the headline that "200,000 await an interest rate shock". 18 The article reports that the crisis threatens to scratch a hole in the pockets of homeowners with ARMs. It also mentions a forecast made by Realkredit Denmark, a leading Danish mortgage lender, saying that some 200,000 homeowners with ARMs can (in the worst case scenario) expect to see monthly rent go up by 1,000 kroner (134 euros).

\footnotetext{
17 “Flekslånere kan få rentechok," Berlingske Tidende, 8 October 2008.

18 "200000 står til rentesmæk," BT, 8 October 2008.
} 
On 14 October 2008 Politiken ran an article with the caption that homeowners with ARMs must keep a cool head. ${ }^{19}$ This article reports that homeowners with ARMs must keep a cool head because (with all the chaos in financial markets) it is completely uncertain what will happen to interest rates in December when ARMs must be refinanced. It also emphasizes that interest rates may still go down.

On 18 October the same newspaper reported that customers storm meetings about ARMs. ${ }^{20}$ The article reports that 200,000 homeowners with ARM are in need of refinancing. The general message is that these homeowners must prepare themselves for large rent increases. It also reports that uncertainty about the level of interest rates is larger than at previous rounds of refinancing.

On 25 October Berlingske was at it again. It ran a piece titled "Interest rate jump hits homeowners hard". ${ }^{21}$ The article reports that homeowners with ARMs can expect higher interest rates and thus higher rent. It also notes that it is the pressure on the krone, which is increasing interest rates, and that no one can know when the pressure on the Danish krone will abate.

On 29 October Politiken also weighed in again. ${ }^{22}$ It ran a piece with the headline that a rescue plan for borrowers with ARMs is underway. This article reports that homeowners with the prospect of a major interest rate increase on their ARMs can take some comfort in the fact that the authorities and the financial sector are working on a rescue plan, which aims at taking the top off the interest rate increases on ARMs.

On 1 November Politiken ran a piece with the headline that a fall in interest rates is the only help to borrowers with ARMs. ${ }^{23}$ The article reports that if the 180,000 homeowners with ARMs

\footnotetext{
19 “Boligejere med flekslån skal have is i maven," Politiken, 14 October 2008.

20 “Kunder løber storm på møder om flekslån," Politiken, 18 October 2008.

21 “Rentehop rammer boligejerne hårdt," Berlingske Tidende, 25 October 2008.

22 “Redningsplan på vej til flekslånere,” Politiken, 29 October 2008.

23 “Et rentefald er eneste hjælp til flekslånere," Politiken, 1 November 2008.
} 
are to avoid a huge rent increase then Danish interest rates must fall. It also reports that interest rates in the Eurozone are expected to decrease, but that it is unclear what will happen in Denmark because of the pressure on the Danish krone. Finally, it reports that the interest rate on ARMs in December 2007 was 4.73\%, whereas the present level is $6.20 \%$.

On 1 December Børsen, the leading Danish business paper, ran a piece entitled "Much uncertainty about the interest rate on ARMs". ${ }^{24}$ The article reports that today ARM auctions have begun. However, it also reports that there is much uncertainty (even among experts) as to the level at which the interest rate will settle. The interest rate spread to the Eurozone can widen if pressure on the krone intensifies. This makes investors nervous, which may necessitate higher interest rates.

Overall, the message from the discussion in this section is that uncertainty about the refinancing of ARMs was rampant in 2008Q4. ${ }^{25}$ Consequently, part of the non-Keynesian effect on consumption growth identified in the regression analysis via the slope estimate, $b_{1}$, may therefore be due to uncertainty over the refinancing of ARMs.

\section{FUTURE CHALLENGES AND TRADE-OFFS FOR THE DANISH EURO PEG}

An implication of the argument so far is that innovations in mortgage finance, particularly the introduction of ARMs, have made monetary policymaking in Denmark more challenging. ARMs have made the economy quite sensitive to changes in short-term interest rates. This is unfortunate in a setting where monetary policy is directed exclusively at maintaining the euro peg, as demonstrated by the unfolding of events during the GFC.

Going forward, Danish policymakers will confront new and difficult challenges and trade-offs. They have learned the hard way that the cost of raising the policy interest has increased substantially. When the cost of raising the policy interest goes up, it becomes harder to defend the euro peg. When homeowners (and thus the Danish economy) are hurt by the central bank's efforts to defend the krone, popular (and perhaps political) support for the euro peg may

\footnotetext{
24 “Boliglån: Stor usikkerhed om rente på flekslån," Børsen, 1 December 2008.

${ }^{25}$ Homeowners can of course reschedule their ARMs to fixed rate mortgages, but that was not profitable at the time given the level of long-term interest rates.
} 
weaken. This increases the probability of (destabilizing) speculation against the krone during financial turmoil, as speculators likely become bolder.

One response by the central bank to counter the above development has been to markedly raise the size of the foreign-exchange reserve, cf. Figure 11. This means that the central bank can, as a first line of defense, rely more intensively on interventions in foreign-exchange markets. This buys the central bank valuable time before it has to raise the policy rate. Yet having a large foreign-exchange reserve is not without costs. As the reserve comprises secure and very liquid assets (primarily deposits in foreign banks and foreign securities, which if necessary can be sold or pledged as collateral at very short notice), there is a non-trivial cost in terms of forgone interest income of a large reserve (Rodrik, 2006). If the cost of forgone interest income proves too burdensome, Danish policymakers will not be able to fully remove any instability of the current regime through continued reserve accumulation.

\section{Insert Figure 11}

One may therefore ask whether the proliferation of ARMs is at all consistent with a fixed exchange rate policy. At the same time, ARMs are being encouraged in subtle ways when they should arguably be taxed or regulated instead due to externality-like effects. More specifically, borrowers (i.e., homeowners) and lenders (i.e., mortgage institutions) do not take into account the fact that they make the protection of the euro peg more difficult. The fact that Danish authorities intervened on several occasions to support the mortgage finance system during the 2008 crisis revealed that ARMs face (Greenspan-type) put-option protection, which may lead to moral hazard issues. For instance, the authorities intervened in order to avoid a fire sale of long-term mortgages in the pension sector, and they intervened to allow a public pension fund to buy for 22 billion kroner adjustable rate mortgages, which amounted to $7 \%$ of the (at the time) expected refinancing activity in the December auction. ${ }^{26}$

Overall, there can be no doubt that the innovations in mortgage finance represents a significant challenge to the conduct of monetary policy in a small open economy with a peg, which during

\footnotetext{
${ }^{26}$ See Børsen, 4 November 2008: “Redningsplaner sender fleksrenter skarpt ned.”
} 
times of turmoil usually experiences a flight to safety (i.e., a flight to a larger currency). That this constellation will prove to have a long life in the absence of some form of adjustment seems unlikely. Some of the contradictions build into this arrangement probably have to go. ${ }^{27}$

\section{CONCLUDING REMARKS}

The GFC hit Denmark exceptionally hard. In this paper we have argued that a combination of innovation in mortgage finance and the need to defend a euro exchange rate peg was partly responsible. Specifically, monetary tightening in the midst of a major cyclical downturn deepened the ongoing recession for the usual Keynesian aggregate demand reasons. Innovation in mortgage finance, which had made the economy more sensitive to changes in the policy rate, intensified this effect. Financial innovation have therefore brought about new and difficult monetary policy trade-offs, which Danish policymakers will have to confront as they seek to manage the euro peg in a post-crisis environment. We have distilled what we believe are the key lessons from the Danish experience, and we hope these will be of some relevance to policymakers facing similar trade-offs in the future.

\footnotetext{
27 Two attempts at neutralizing some of these contradictions deserve brief mentioning. First, since June 2014 ARM refinancing auctions take place each quarter (i.e., in March, June, September, and December). This is thought to reduce macroeconomic refinancing risks. Second, a legislative amendment, which introduces contingent maturity extension of mortgage bonds, was adopted in March 2014. The maturity extension takes effect if an auction fails or if the interest rate rises by more than five percentage points (the so-called the interest-rate trigger). Note, however, that to the extent that the uncertainty effect is important, quarterly auctions may be less effective than expected as consumers react strongly to uncertainty. Moreover, the interest-rate trigger would not have been activated in 2008Q4 (had the legislation actually been adopted at that time).
} 


\section{REFERENCES}

Alexopoulos, M, and Cohen, J. 2009: Uncertain Times, Uncertain Measures. Working Paper, tecipa-352, University of Toronto: Toronto.

Andersen, AL, Duus, C, and Jensen, TL. 2014: Household Debt and Consumption During the Financial Crisis. Danmarks Nationalbank Monetary Review $1^{\text {st }}$ Quarter: 61-71.

Andersen, TB and Malchow-Møller N. 2014: Denmark's fixed exchange rate regime and the delayed recovery from the Global Financial Crisis: A comparative macroeconomic analysis. Unpublished manuscript, University of Southern Denmark: Odense.

Baker, SR, Bloom, N and Davis, SJ. 2012: Measuring Economic Policy Uncertainty. Chicago Booth Research Paper No. 13-02: Chicago.

Benassy-Quéré, A, Cæuré, B, Jacquet, P, and Pisani-Ferry, J. 2010: Economic Policy: Theory and Practice. Oxford University Press: Oxford.

Bernanke, B. 1983: Irreversibility, Uncertainty, and Cyclical Investment. Quarterly Journal of Economics 98(1): 85-106.

Bloom, N. 2014: Fluctuations in Uncertainty. Journal of Economic Perspectives 28(2): 153-176.

Bloom, N, Floetotto, M, Jaimovich, N, Saporta-Eksten, I and Terry, SJ. 2012: Really Uncertain Business Cycles. NBER Working Paper 18245, National Bureau of Economic Research: Cambridge, MA.

Carnot, N, Koen, V and Tissot, B. 2011: Economic Forecasting and Policy. Second Edition, Palgrave Macmillan

Danmarks Nationalbank. 2009: Monetary Policy in Denmark. Third Edition 
Dixit, AK and Pindyck, RK. 1994: Investment under Uncertainty. Princeton University Press: Princeton, NJ.

ECB. 2003: Policy Position of the Governing Council of the European Central Bank on Exchange Rate Issues Relating to the Acceding Countries. European central Bank, 18 December, https://www.ecb.europa.eu/pub/pdf/other/policyaccexchangerateen.pdf, accessed 30 December 2014.

Eichengreen, B and Temin, P. 2000: The Gold Standard and the Great Depression. Contemporary European History 9(2): 183-207.

Erhvervs- og Vækstministeriet. 2013: Den Finansielle Krise i Danmark—Årsager, konsekvenser og læring. Erhvervs- og Vækstministeriet, 15 September, http://www.evm.dk/publikationer/2013/18-09-13-den-finansielle-krise-i-danmark, accessed 30 December 2014.

Fernández-Villaverde, J, Guerrón-Quintana, P, Rubio-Ramirez, JF and Uribe, M. 2011: Risk Matters: The Real Effects of Volatility Shocks. American Economic Review 101(6): 2530-61.

Finanstilsynet. 2008: Realkreditinstitutter: Statistisk material 2008. Table 2.4, https://www.finanstilsynet.dk/da/Tal-og-fakta/Statistik-noegletal-analyser/Statistik-omsektoren/2008/Realkreditinstitutter-Statistisk-materiale-2008.aspx, accessed 30 December 2014.

IMF. 2010: Staff Report for the 2010 Article IV Consultation. IMF Country Report No. 10/365, International Monetary Fund: Washington, DC.

Johansen, PU and Trier, M. 2013: Danmarks økonomi siden 1980-en oversigt. Handelshøjskolens forlag: København.

Kraka. 2014: Den danske finanskrise-kan det ske igen? Finanskrisekommissionen: København. 
Nielsen, S. 2007: Håndbog i Boligfinansiering. Forlaget Thomson: København.

OECD. 2006: OECD Economic Surveys: Denmark. Organization for Economic Co-operation and Development: Paris.

OECD. 2009: OECD Economic Surveys: Denmark. Organization for Economic Co-operation and Development: Paris.

OECD. 2010: Economic Survey of Finland 2010: Overcoming the crisis and beyond. Organization for Economic Co-operation and Development: Paris.

Rodrik, D. 2006: The Social Cost of Foreign Exchange Reserves. NBER Working Paper 11952, National Bureau of Economic Research: Cambridge, MA.

Romer, CD. 1990: The Great Crash and the Onset of the Great Depression. Quarterly Journal of Economics 105(3): 597-624.

Romer, D. 2012: Advanced Macroeconomics. Fourth Edition, McGraw-Hill: New York.

Stiglitz, JE. 2002: Globalization and Its Discontents. W. W. Norton \& Company, Inc.: New York. Sørensen, PB. 2012: Vismændene og dansk økonomi i 00erne. DØRS Jubilæumsskrift: 32-47.

Sørensen, PB. 2010: Nedturen i Dansk økonomi-Hvor meget var selvforskyldt? Samfundsøkonomen 1(Marts): 29-35.

Wendt, P. 2011: Den finansielle sektor. Handelshøjskolens forlag: København.

Wooldridge, JM. 2013: Introductory Econometrics. Fifth International Edition, South-Western 


\section{FIGURES AND TABLES}

Figure 1: Average annual real GDP growth (\%), 2007-2009.

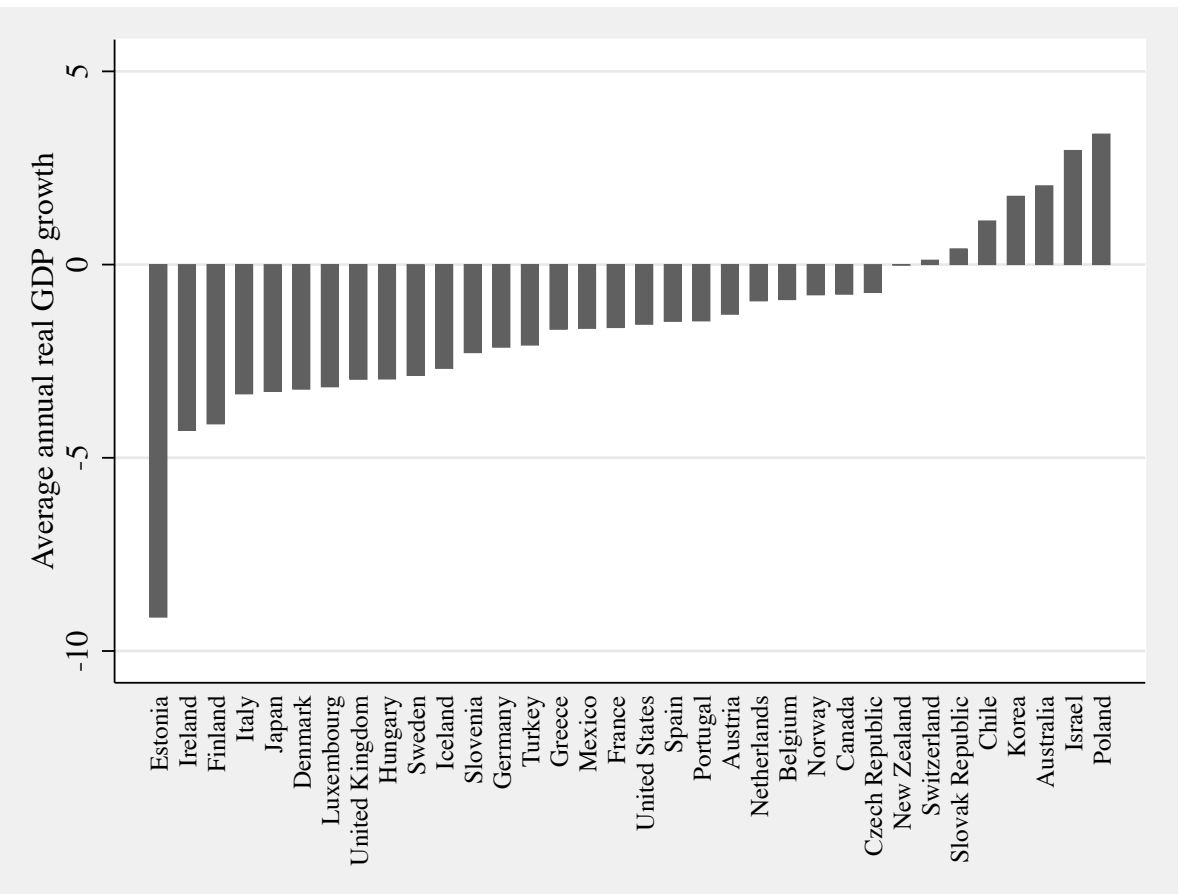

Notes: Average annual growth is calculated as $\left(\sqrt[2]{G D P_{2009} / G D P_{2007}}-1\right) \cdot 100 \%$. Data source is OECD Economic Outlook Database, May 2014. 
Figure 2: Policy interest rate in Denmark and Eurozone (\%).

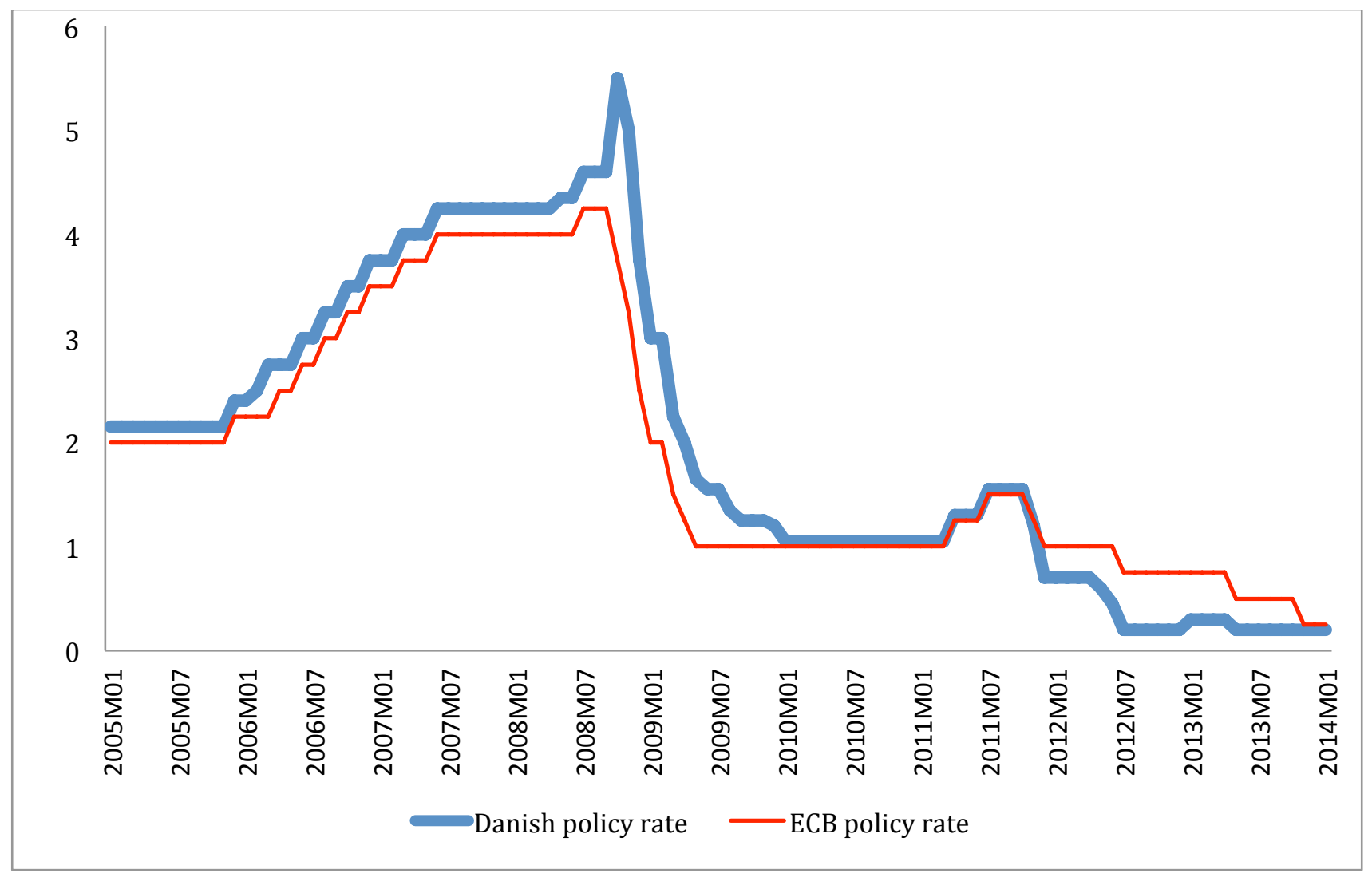

Notes: Danmarks Nationalbank's lending rate and the ECB's marginal rate on its main refinancing operations (end-of-month values). Sources are Danmarks Nationalbank and the European Central Bank. 
Figure 3: Short-term interest rate in Denmark and Germany (\%).

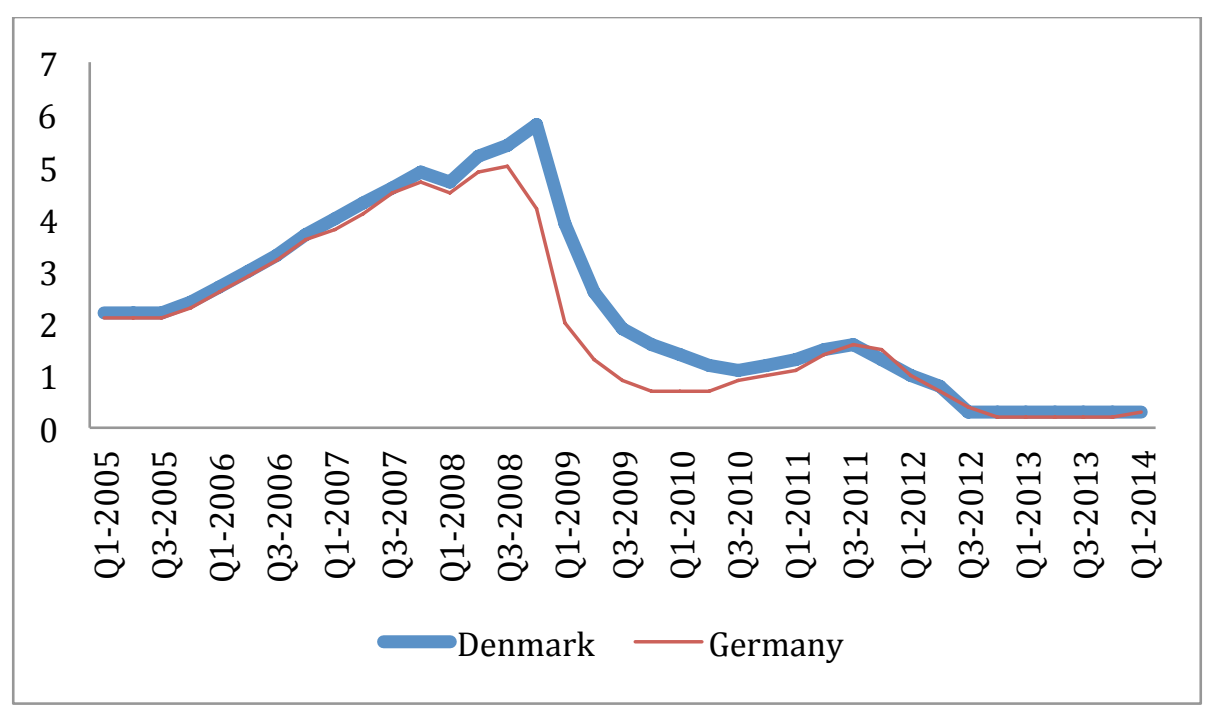

Notes: Short-term (3-month) interest rates are usually either the three month interbank offer rate attached to loans given and taken amongst banks for any excess or shortage of liquidity over several months or the rate associated with Treasury bills, Certificates of Deposit or comparable instruments, each of three month maturity. Source is OECD Economic Outlook, May 2014. 
Figure 4: Short-term interest rate spread (\%-points) between Denmark and Germany.

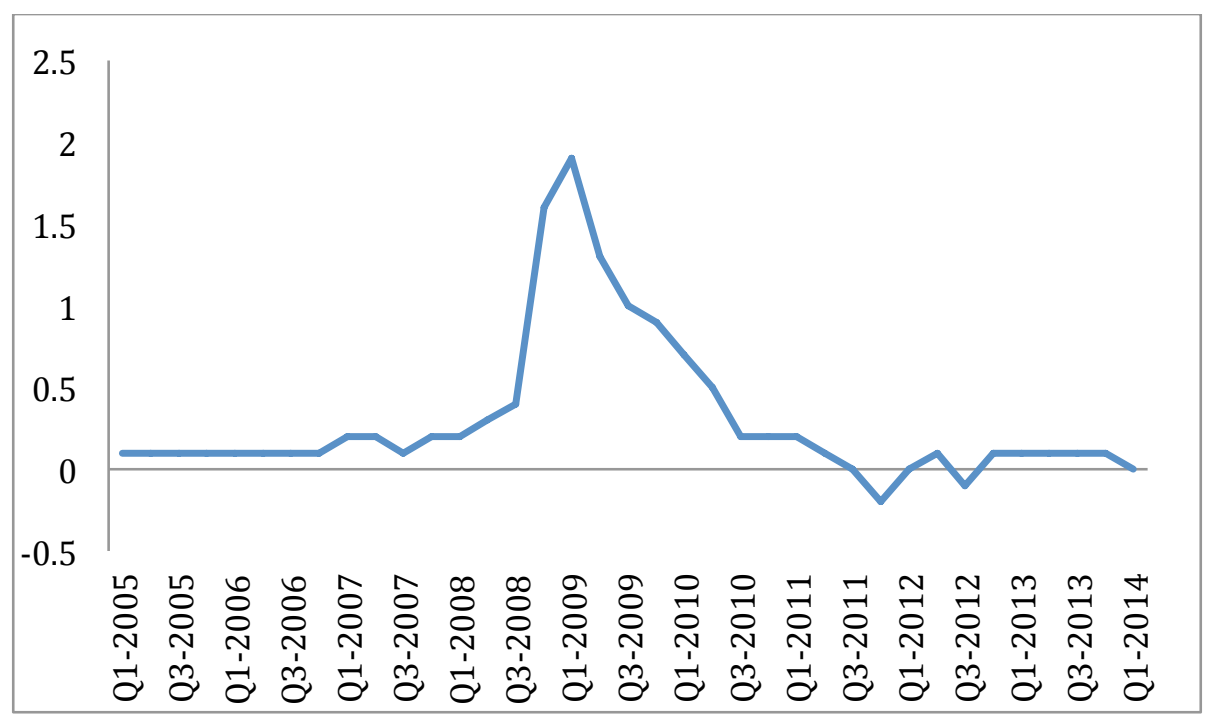

Notes: See text below Figure 3. Source is OECD Economic Outlook, May 2014. 
Figure 5: Long-term interest rate spread (\%-points) between Denmark and Germany.

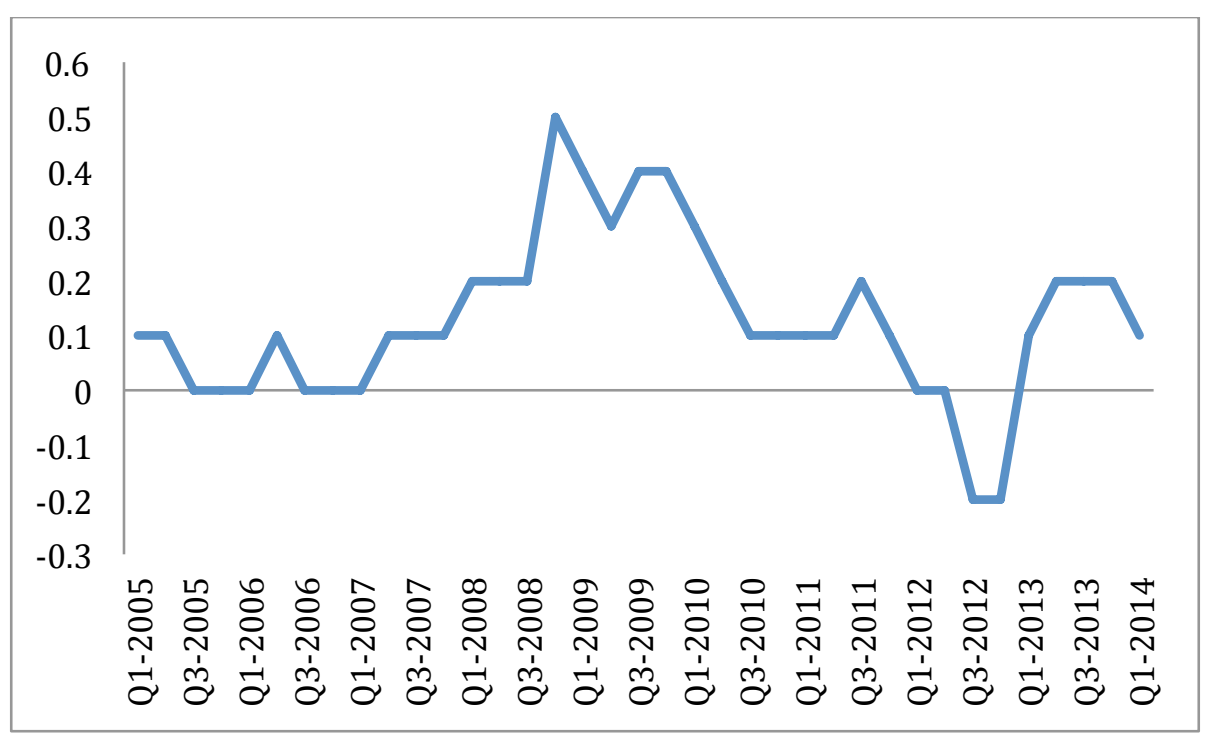

Notes: Long-term (mostly 10 year) government bonds are the instruments whose yield is used as the representative interest rate for this area. Generally the yield is calculated at the pre-tax level and before deductions for brokerage costs and commissions and is derived from the relationship between the present market value of the bond and that at maturity, taking into account also interest payments paid through to maturity. Source is OECD Economic Outlook, May 2014. 
Figure 6: Danish households' purchases of vehicles.

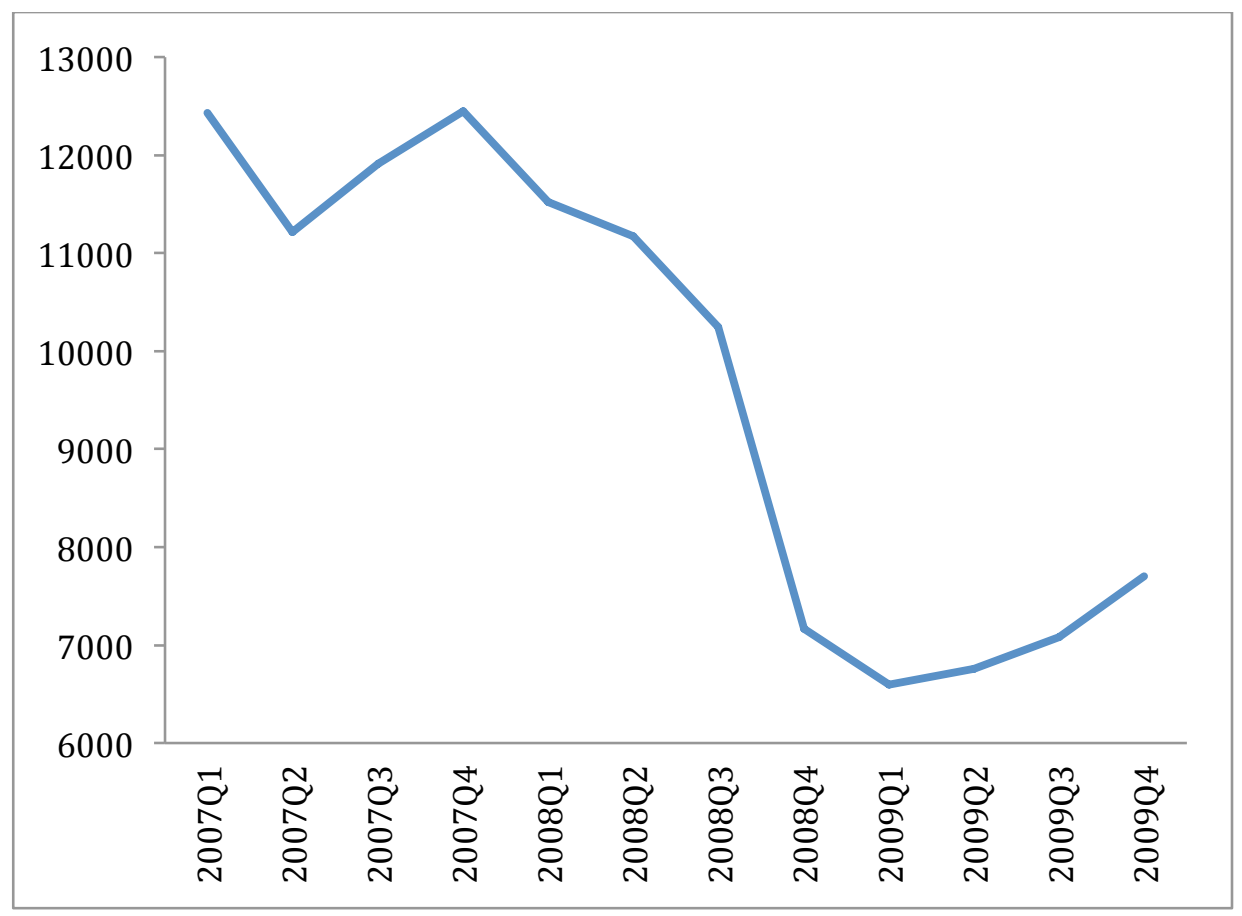

Notes: Constant chained 2005 kroner (millions). Data are seasonally and trading-day adjusted. Source is Statistics Denmark. 
Figure 7: Growth in private final consumption (volume) during 2008Q4.

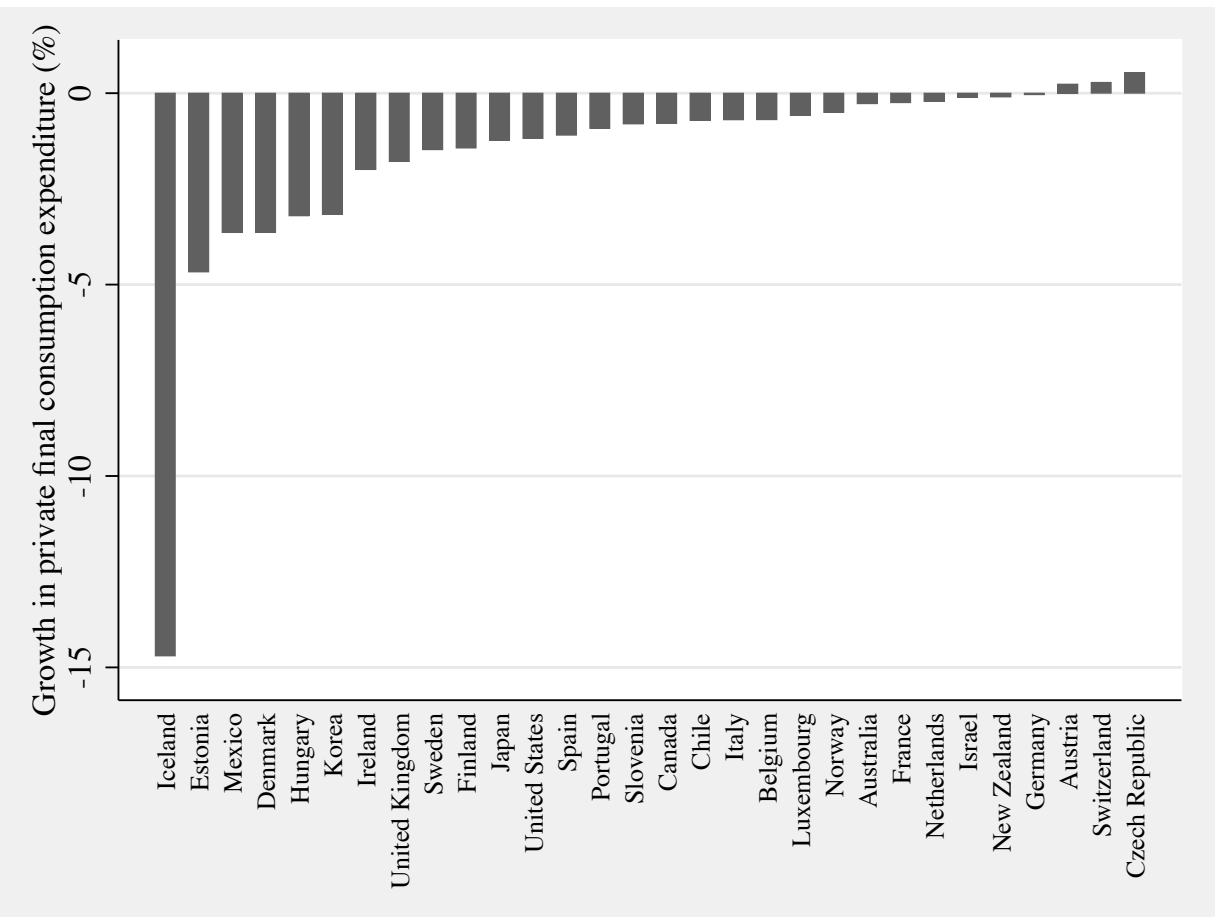

Notes: Private final consumption is purchases of goods and services used by households to meet their everyday needs (i.e., clothing, household durables, rent, transport, etc.). Source is OECD Economic Outlook, May 2014. 
Figure 8: Evolution of private final consumption (volume) $(2008 \mathrm{Q} 3=100)$.

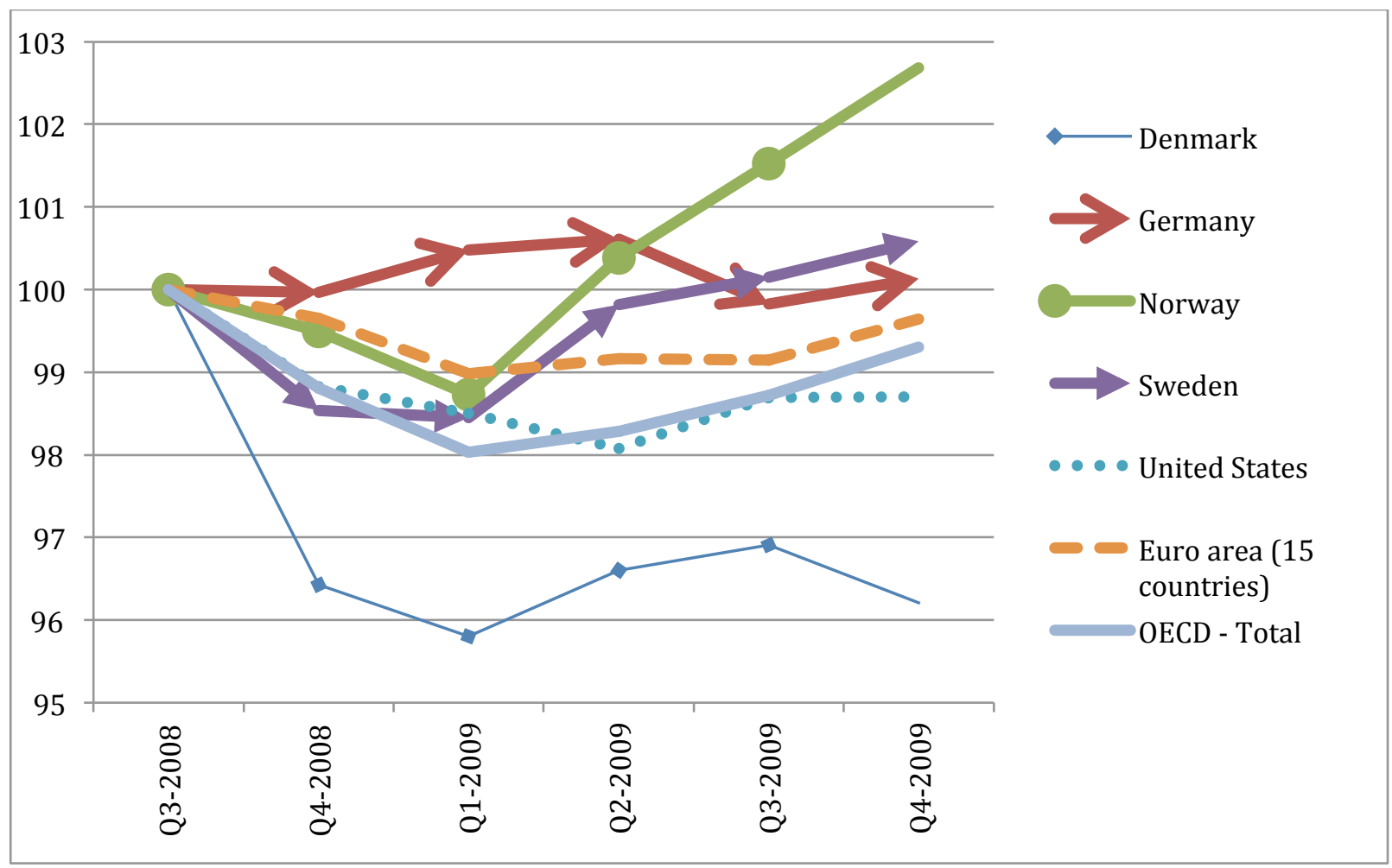

Notes: See Figure 7. Source is OECD Economic Outlook, May 2014. 
Figure 9: Percentage change in quarterly (realized) housing prices.

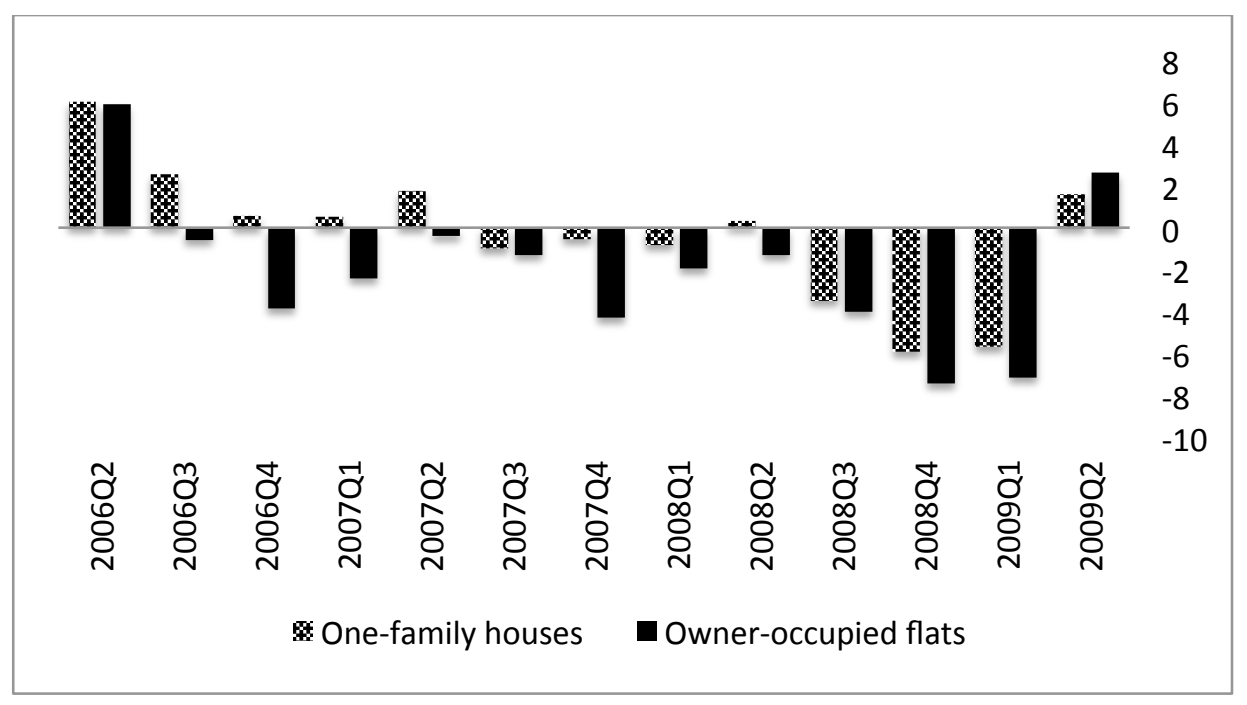

Notes: Source is the Association of Danish Mortgage Banks (series BM010). 
Figure 10: Occurrences of the words "rentetilpasningslån" and "usikkerhed" in newspapers

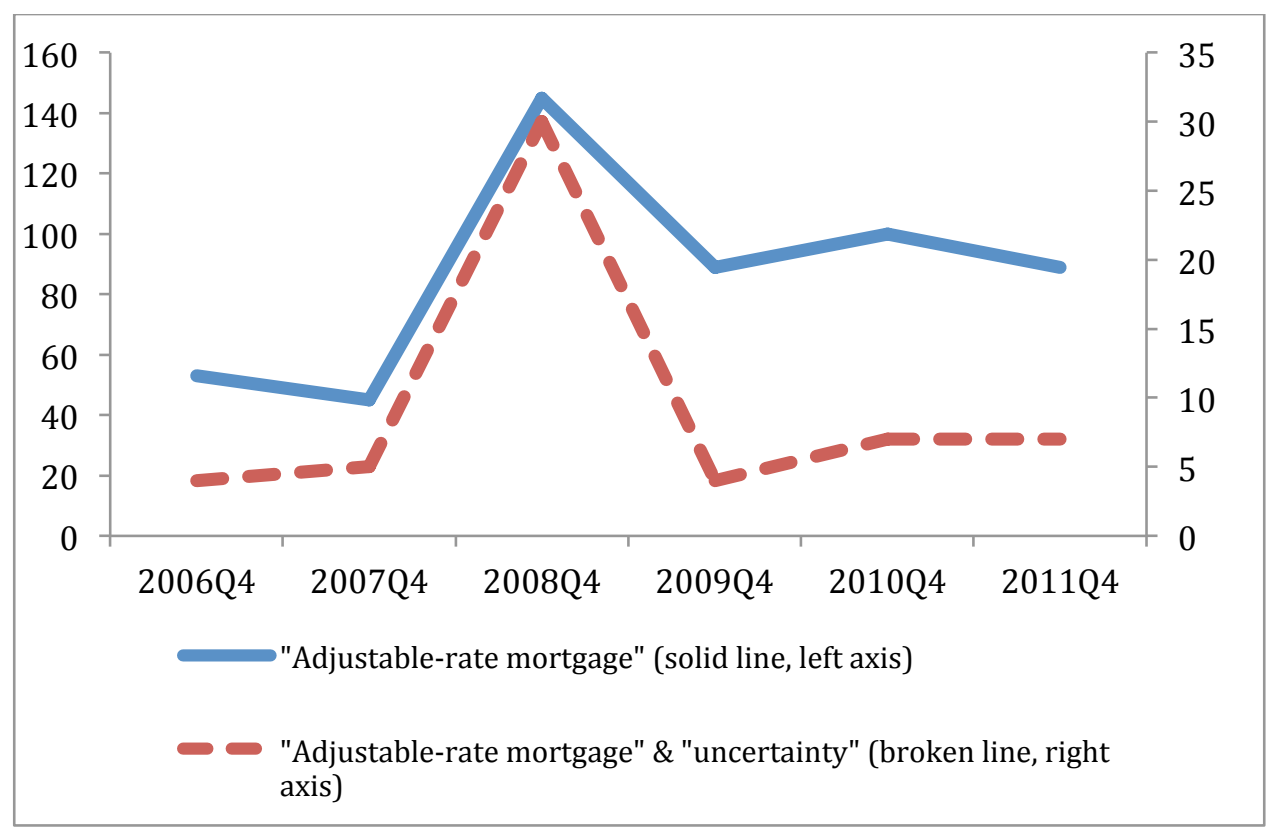

Notes: Search in the Danish media database INFOMEDIA on the number of articles featuring the words "rentetilpasningslån" (i.e., adjustable-rate mortgage or adjustable-rate mortgages) and "usikkerhed" (i.e., uncertainty) in the following national Danish newspapers: Berlingske, BT, Børsen, Ekstra Bladet, Information, Jyllands-Posten, Kristelig Dagblad, Politiken, and Weekendavisen. In Danish the word "rentetilpasningslån" is the same in singular and plural, for which reason we are in effect including both "adjustable-rate mortgage" and "adjustablerate mortgages" in our search. The solid line refers to a search on only ARMs, and it is measured on the left axis. The broken line refers to a search on ARMs and uncertainty, and it is measured on the right axis. 
Figure 11: Danish foreign exchange-rate reserve (kroner billions)

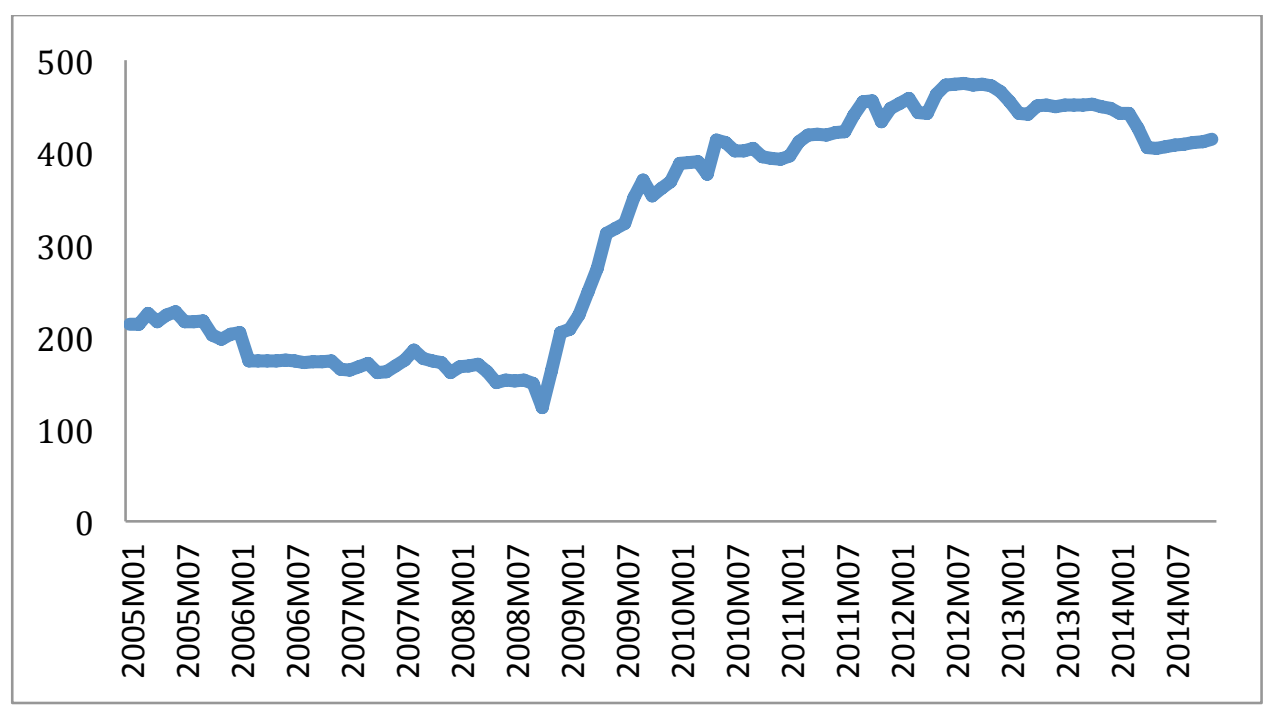

Notes: The source is Danmarks Nationalbank's statistical databank. 
Table 1: OLS estimation, sample period 1999Q1-2014Q1

\begin{tabular}{|c|c|c|c|c|}
\hline & (1) & (2) & (3) & (4) \\
\hline Dependent variable: & gcons $_{t}$ & gcons $_{t}$ & $\operatorname{gcar}_{t}$ & gcar $_{t}$ \\
\hline \multirow[t]{2}{*}{ spread $_{t}$} & $-1.048^{* *}$ & $-1.157^{* *}$ & $-6.147^{*}$ & $-7.423^{* *}$ \\
\hline & {$[-0.354]$} & {$[-0.380]$} & {$[-0.266]$} & {$[-0.314]$} \\
\hline \multirow[t]{2}{*}{$r_{t}^{10 y}$} & $0.428^{* *}$ & $0.604^{* *}$ & $2.812^{*}$ & $4.636^{* *}$ \\
\hline & [0.459] & {$[0.536]$} & [0.387] & [0.531] \\
\hline \multirow[t]{2}{*}{$r_{t}^{3 m}$} & -0.262 & $-0.318^{*}$ & $-3.224^{* *}$ & $-4.459^{* * *}$ \\
\hline & {$[-0.364]$} & {$[-0.378]$} & {$[-0.574]$} & {$[-0.684]$} \\
\hline \multirow[t]{2}{*}{ ghouse $_{t}$} & $0.122^{* *}$ & 0.103 & 0.552 & 0.382 \\
\hline & {$[0.279]$} & {$[0.231]$} & {$[0.162]$} & {$[0.111]$} \\
\hline \multirow[t]{2}{*}{ gcons $_{t-1}$} & $-0.344^{* * *}$ & $-0.391^{* * *}$ & & \\
\hline & {$[-0.349]$} & {$[-0.395]$} & & \\
\hline \multirow[t]{2}{*}{$\operatorname{gcar}_{t-1}$} & & & -0.191 & $-0.261^{*}$ \\
\hline & & & {$[-0.194]$} & {$[-0.263]$} \\
\hline Constant & -0.339 & -0.694 & -0.170 & -2.778 \\
\hline $\begin{array}{l}\text { Durbin alternative test } \\
\text { ( } p \text {-value) }\end{array}$ & 0.188 & 0.412 & 0.699 & 0.387 \\
\hline \multirow[t]{2}{*}{ Adjusted R2 } & 0.259 & 0.279 & 0.214 & 0.277 \\
\hline & 1999Q1- & 2002Q1- & 1999Q1- & 2002Q1- \\
\hline Sample period & 2014Q1 & 2014Q1 & 2014Q1 & 2014Q1 \\
\hline Observations & 59 & 49 & 59 & 49 \\
\hline
\end{tabular}

Notes: gcons $_{t}$ is the quarterly growth rate in real household consumption expenditure. gcar $_{t}$ is the quarterly growth rate in household's purchases of vehicles. Both $g_{\text {cons }}$ and gcar $_{t}$ are seasonally adjusted and the data source is Statistics Denmark. ghouse $e_{t}$ is the quarterly growth rate in realized house prices. Data are from the Association of Danish Mortgage Banks. Asterisk $* * *, * *$, and $*$ denote statistical significance at 1,5 , and $10 \%$ respectively. Standardized coefficients are reported in square brackets. Durbin alternative test tests the null of no autocorrelation. 
34

Appendix Table A1: Graphs of the series used in the empirical analysis
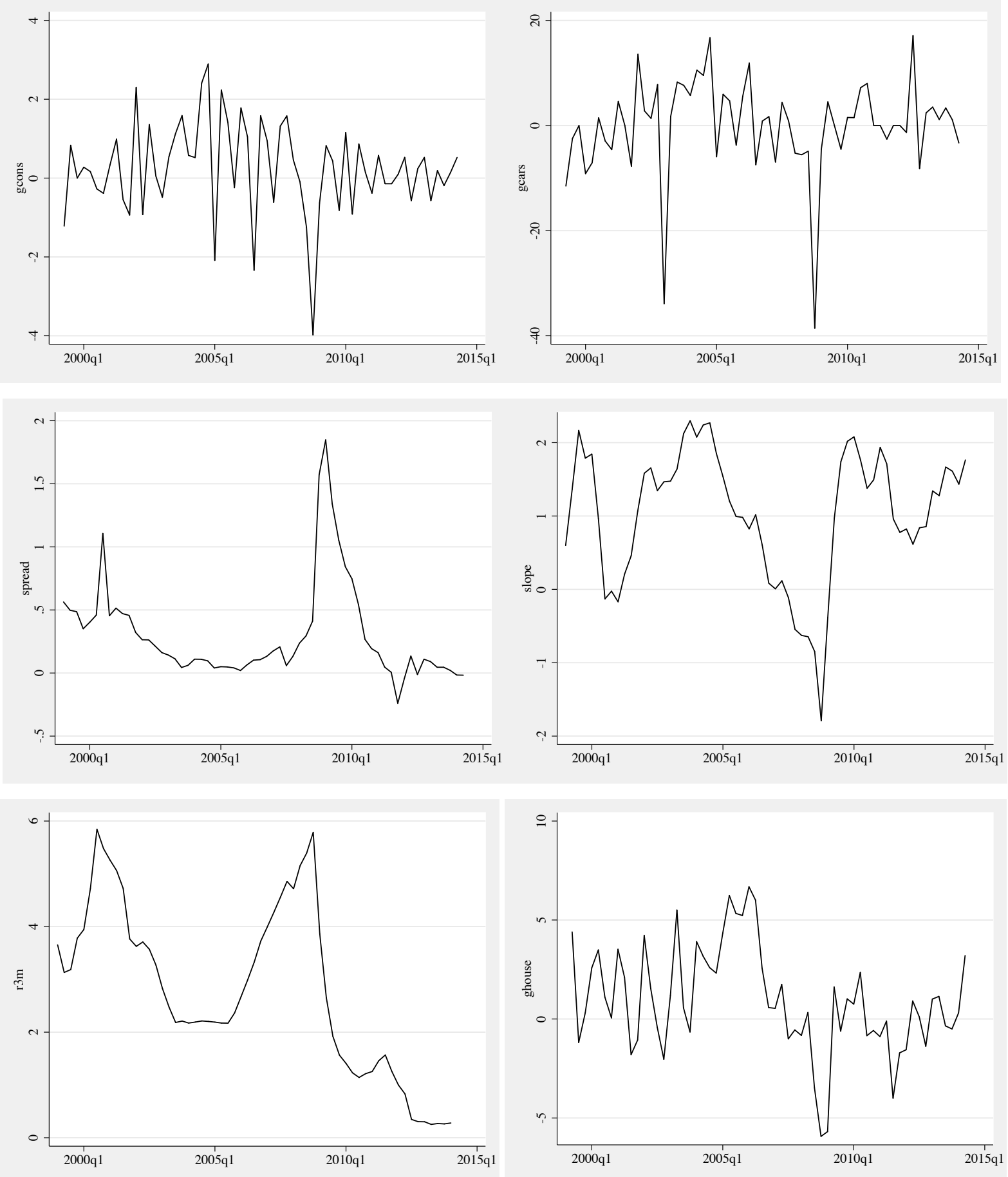